
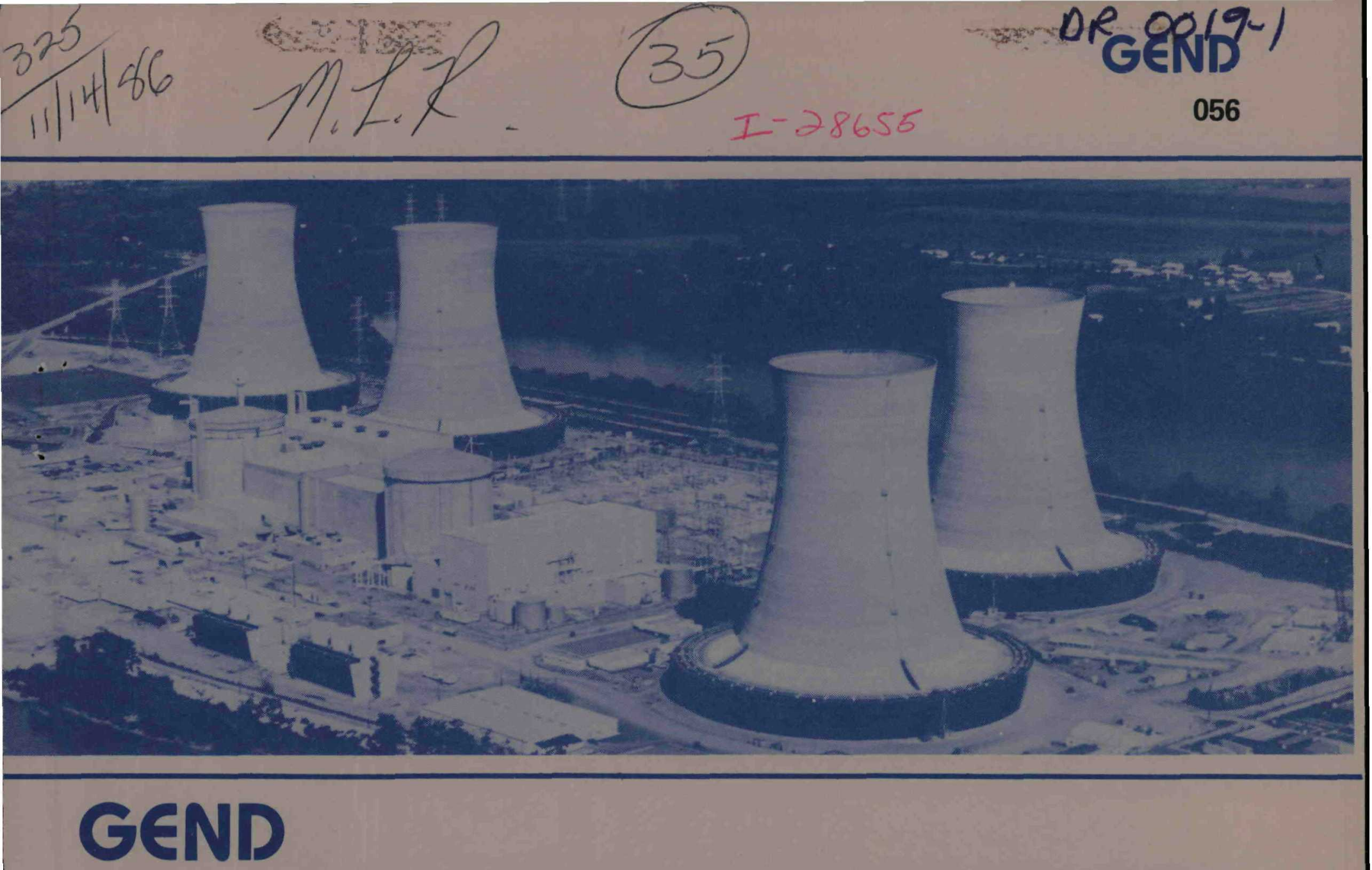

General Public Utilities • Electric Power Reseorch Institute • U.S. Nuclear Regulatory Commission • U.S. Department of EnergY

\title{
TMI-2 Instrumentation and Electrical Program Final Evaluation Report
}

C.W. Mayo

J.M. Huzdovich

A.R. Roby

L.D. Test

November 1986

Prepared for the U.S. Department of Energy

Three Mile Island Operations Office Under DOE Contract No. DE-AC07-76ID01570

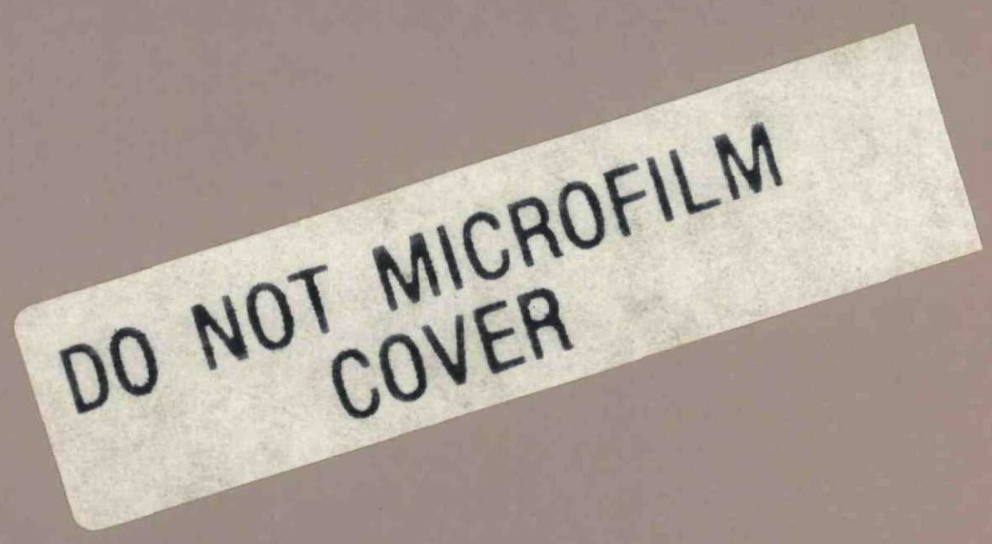




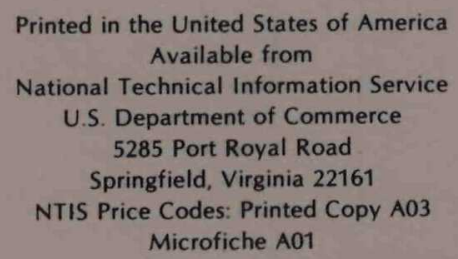

\section{DO NOT MICROFILM COVER}

\section{DISCLAIMER}

This book was prepared as an account of work sponsored by an agency of the United States Government. Neither the United States Government nor any agency thereof, nor any of their employees, makes any warranty, express or implied, or assumes any legal liability or responsibility for the accuracy, completeness, or usefulness of any information, apparatus, product or process disclosed, or represents that its use would not infringe privately owned rights. References herein to any specific commercial product, process, or service by trade name, trademark, manufacturer, or otherwise, does not necessarily constitute or imply its endorsement, recommendation, or favoring by the United States Government or any agency thereof. The views and opinions of authors expressed herein do not necessarily state or reflect those of the United States Government or any agency thereof. 


\section{DISCLAIMER}

This report was prepared as an account of work sponsored by an agency of the United States Government. Neither the United States Government nor any agency Thereof, nor any of their employees, makes any warranty, express or implied, or assumes any legal liability or responsibility for the accuracy, completeness, or usefulness of any information, apparatus, product, or process disclosed, or represents that its use would not infringe privately owned rights. Reference herein to any specific commercial product, process, or service by trade name, trademark, manufacturer, or otherwise does not necessarily constitute or imply its endorsement, recommendation, or favoring by the United States Government or any agency thereof. The views and opinions of authors expressed herein do not necessarily state or reflect those of the United States Government or any agency thereof. 


\section{DISCLAIMER}

Portions of this document may be illegible in electronic image products. Images are produced from the best available original document. 


\title{
DISCLAIMER
}

This report was prepared as an account of work sponsored by an agency of the United States Government. Neither the United States Government nor any agency thereof, nor any of their employees, makes any warranty, express or implied, or assumes any legal liability or responsibility for the accuracy, completeness, or usefulness of any information, apparatus, product, or process disclosed, or represents that its use would not infringe privately owned rights. Reference herein to any specific commercial product, process, or service by trade name, trademark, manufacturer, or otherwise does not necessarily constitute or imply its endorsement, recommendation, or favoring by the United States Government or any agency thereof. The views and opinions of authors expressed herein do not necessarily state or reflect those of the United States Government or any agency thereof.

\section{TMI-2 INSTRUMENTATION AND ELECTRICAL PROGRAM FINAL EVALUATION REPORT}

GEND 056

Distribution Category: UC-78

TMI Supplement

\author{
GEND--056 \\ C.W. Mayo \\ J.W. Huzdovich \\ DE $87 \quad 002273$ \\ A.R. Roby \\ L.D. Test
}

Published November 1986

EG\&G Idaho, Inc. Idaho Falls, Idaho 83415

\author{
Prepared for the \\ U.S. Department of Energy \\ Three Mile Island Operations Office \\ Under DOE Contract No. DE-AC07-76ID01570
}




\section{ABSTRACT}

This report presents the authors collective opinions on the value to the nuclear industry of the various investigations performed at TMI-2 by the Instrumentation and Electrical Program. The authors demonstrate that more attention must be given to the prevention of moisture intrusion during design, construction, operation, and maintenance of a nuclear power $p l a n t$. They also point out that, while basic engineering designs of instruments are more than adequate, the applications engineering and specifications could be improved. Finally, they show that advanced testing technology, exemplified by the Electrical Circuit Characterization and Diagnostics (ECCAD) System, may be very useful as a diagnostic tool when used as part of the testing or maintenance program in a nuclear power plant. 


\section{FOREWORD}

This report was prepared by the authors acting as a special comittee of the Technical Evaluation Group. The technical evaluation group was comprised of several experts in the fields of instrumentation and electrical equipment and was selected to monitor and critique the Instrumentation and Electrical (I\&E) Program at Three Mile Island Unit 2.

Over the last four years, the Technical Evaluation Group met periodically to review progress of the TMI-2 I\&E program and to give guidance for further investigations to provide the greatest return to the nuclear industry.

The TMI-2 I\&E Program has accomplished its program objectives and has disbanded.

Thanks are given to the experts who volunteered to participate on the Technical Evaluation Group and their respective organizations and to the principal investigators who did the work and authored the technical reports.

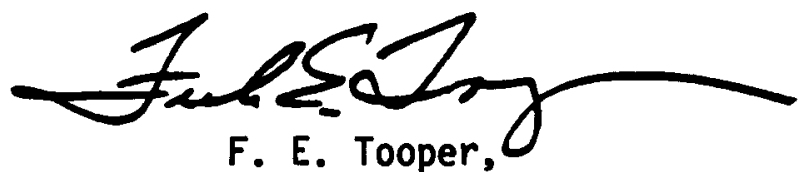

Program Manager

DOE-HQ

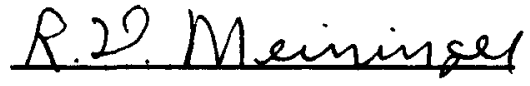

R. D. Meininger Program Manager EG\&G Idaho, Inc. 


\section{CONTENTS}

ABSTRACT $\ldots \ldots \ldots \ldots \ldots \ldots \ldots \ldots \ldots \ldots \ldots \ldots \ldots \ldots \ldots \ldots \ldots \ldots \ldots \ldots \ldots \ldots$

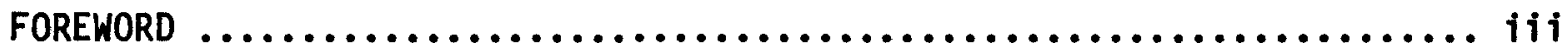

CONTENTS $\ldots \ldots \ldots \ldots \ldots \ldots \ldots \ldots \ldots \ldots \ldots \ldots \ldots \ldots \ldots \ldots \ldots \ldots \ldots \ldots \ldots \ldots$

INTRODUCTION $\ldots \ldots \ldots \ldots \ldots \ldots \ldots \ldots \ldots \ldots \ldots \ldots \ldots \ldots \ldots \ldots \ldots \ldots \ldots \ldots \ldots \ldots \ldots \ldots$

APPLICATIONS ENGINEERING AND EQUIPMENT SPECIFICATION $\ldots \ldots \ldots \ldots \ldots \ldots \ldots$

Examples of Inadequacies $\ldots \ldots \ldots \ldots \ldots \ldots \ldots \ldots \ldots \ldots \ldots \ldots \ldots \ldots$

Applications Engineering $\ldots \ldots \ldots \ldots \ldots \ldots \ldots \ldots \ldots \ldots \ldots \ldots \ldots$

Specifications $\ldots \ldots \ldots \ldots \ldots \ldots \ldots \ldots \ldots \ldots \ldots \ldots \ldots \ldots \ldots \ldots \ldots$

INSTALLATION AND TESTING $\ldots \ldots \ldots \ldots \ldots \ldots \ldots \ldots \ldots \ldots \ldots \ldots \ldots \ldots \ldots \ldots \ldots \ldots$

Installation $\ldots \ldots \ldots \ldots \ldots \ldots \ldots \ldots \ldots \ldots \ldots \ldots \ldots \ldots \ldots \ldots \ldots \ldots \ldots$

Testing $\ldots \ldots \ldots \ldots \ldots \ldots \ldots \ldots \ldots \ldots \ldots \ldots \ldots \ldots \ldots \ldots \ldots \ldots \ldots \ldots \ldots \ldots$

OPERATIONS AND MAINTENANCE $\ldots \ldots \ldots \ldots \ldots \ldots \ldots \ldots \ldots \ldots \ldots \ldots \ldots \ldots \ldots$

Findings $\ldots \ldots \ldots \ldots \ldots \ldots \ldots \ldots \ldots \ldots \ldots \ldots \ldots \ldots \ldots \ldots \ldots \ldots \ldots \ldots \ldots$

Predictive Maintenance.$\ldots \ldots \ldots \ldots \ldots \ldots \ldots \ldots \ldots \ldots \ldots \ldots \ldots \ldots \ldots$

REFERENCES $\ldots \ldots \ldots \ldots \ldots \ldots \ldots \ldots \ldots \ldots \ldots \ldots \ldots \ldots \ldots \ldots \ldots \ldots \ldots \ldots \ldots$

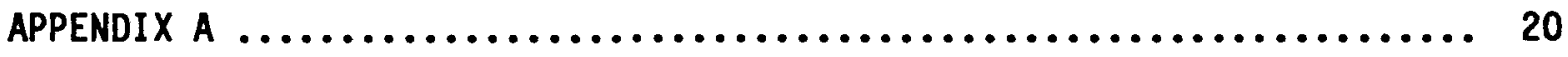




\section{INTRODUCTION}

The accident at Three Mile Island Unit 2 (TMI-2) provided an opportunity to evaluate a variety of instrumentation and electrical equipment for the effects of exposure to moderately severe accident conditions including steam, spray, radiation, hydrogen burn, and the resultant overpressure. The examination of this equipment over a period of several years also provided information on long-term exposure to moisture. The TMI-2 Instrumentation and Electrical (I\&E) Program results support the general conclusion that the $\mathrm{plant}$ instrumentation and electrical equipment performed well with respect to its required function under the accident conditions.

The TMI-2 I\&E Program also identified and analyzed a number of installation problems and instrument response characteristics that led to misleading information and equipment failures. These problems included faulty seals and inadequate drains and vents to protect enclosed equipment against moisture, anomalous response of radiation monitors, and substantial corrosion of electrical contacts over a period of a few years. The equipment involved included the radiation monitors from which it has not been possible to determine the true radiation profile within the Reactor Butlding; pressure transmitters which failed due to moisture intrusion; the loose parts monitors which degraded and then failed due to the sensitivity of the electronics to radiation; various switches and contacts which are continuing to fail due to corrosion; solenoid operators for valves which trapped moisture within the assembly; and various other devices which suffered from moisture intrusion.

Many of the active equipment problems could have been prevented through design and installation practices that would have prevented moisture intrusion. The response of the radiation monitors could have been improved through improved designs and testing. The corrosion problems observed over the course of the program may represent another form of aging of electrical equipment. The means to accelerate these phenomenon for test 
purposes are not presently well known. The best approach is to specify designs which prevent moisture intrusion.

The Electrical Circuit Characterization and Diagnostic (ECCAD) system developed by the TMI-2 I\&E Program as a research tool was shown to have general applications for diagnosis of electrical circuits. Applications include the detection of moisture, surface conduction and contact corrosion problems, some types of cable damage, and the verification of correct circuit terminations. This system provides an integrated application of fundamental measurements and techniques developed by aerospace research to detect electrical circuit degradation. This system is currently being evaluated in a joint program with the Duke Power Company to determine its feasibility to support electrical maintenance as a diagnostics instrument. The system is, however, one of several techniques presently available. The results of the TMI-2 R\&D in this regard should not be construed as a recommendation to require ECCAD monitoring as part of operating plant surveillance programs. 


\section{APPLICATIONS ENGINEERING AND EQUIPMENT SPECIFICATION}

The examination of damaged equipment removed from the reactor building at TMI-2 revealed a large number of problems that could only be attributed to inadequately specifying the equipment for the actual application. This was evident in moisture intrusion through equipment interface paths, energy dependence of the reactor building dome radiation monitor response, effects of field cable length on area radiation monitor indicators, and the failure of radiation sensitive semiconductors. These problems, described below, can be directly related to inadequate applications engineering and the faiture of specifications to define what was required or expected of the equipment. They are discussed to illustrate aspects of applications engineering and equipment specification that need attention.

TMI-2 was not unique in its specification or installation practices and the observed problems can happen during normal power plant operations. The TMI-2 accident demonstrated that while most of the equipment satisfied its design intent, there were numerous cases of equipment being damaged or degraded, long after the accident was terminated, by moisture or accumulated radiation. These conditions, along with the thermal stress, are not unusual for a nuclear power plant and can be adequately dealt with if they are specified as part of the equipment application.

\section{Examples of Inadequacies}

- Pressure Transmitters ${ }^{1-4}$

Seven pressure transmitters, of 58 available, were removed from the TMI-2 Reactor Building for evaluation at the Idaho National Engineering Laboratory (INEL). Of the seven transmitters, three were made by Manufacturer $A$ and four by Manufacturer B. A11 of the A units survived the accident and post accident. One of the $B$ units survived the accident and post accident, and another $B$ unit survived the accident and one year of post accident before failing. All seven transmitters were removed from locations above flood level and were exposed to approximately the same environment. 
During the course of the evaluation of the effects of the accident on the instrumentation it became evident that many of the observed failures resulted from improper specifications of equipment.

A11 failures were attributed to moisture intrusion into the electronic component volume resulting in failure of electronic components. Those units that survived had either an adquate internal seal

(Manufacturer A) or a properiy installed conduit and junction box (one of Manufacturer B's transmitters). A proper performance or installation specification calling for either sealing the transmitter or for a junction box with breather, drain, and correct conduit entry would have precluded moisture intrusion.

The fact that one of the unsealed $B$ units survived the accident and operated for a full year thereafter, 1 meeting or exceeding most current nuclear plant requirements, reinforces the importance of the interface specification in assuring the performance of an otherwise reliable instrument.

- Dome Monitor 5

The reactor building dome radiation monitor, with shielded ion chambers and electronics, was the only radiation monitor inside the Reactor Building with the required capability to measure and indicate LOCA-level radiation. This monitor was the subject of extensive examination in efforts to understand the monitor response and to determine radiation levels inside the Reactor Building during the accident.

The dome monitor design indicated that little consideration had been given the fact that the energy content of the accident radiation changes with time during the course of an accident. By not requiring a flat gamma energy response, as evidenced by using a lead shield around the ion chamber, radiation measurement inaccuracies were assured. Also, the electronics (specifically the MOS transistors) were significantly degraded by radiation exposure, suggesting that the 
specification did not require qualification to accident radiation dose levels. Analysis of post-accident radiation energy as a function of time, and testing the dome monitor design for post-accident radiation dose levels, could have led to a proper specification for this equipment.

The dome monitor also appeared to have experienced moisture intrusion. The major cause was an installation error that provided a path for moisture intrusion. This may have masked a potential design problem, in that the examination results indicated that the main seal, a large-circumference o-ring, may have also leaked. Circuit analysis and testing indicated that the electronic design was sensitive to moisture in a manner that could significantly alter the indicated radiation level. A specification that required equipment performance to be proven under predicted accident environmental conditions might have resulted in correction of these failure mechanisms.

- Area Radiation Monitors $6-9$

Three radiation monitors were selected for early removal in an attempt to establish an improved knowledge of radiation levels during the accident. All three were located in the Reactor Building and were exposed to the accident and post-accident environment. All three monitors were of the Geiger-Mueller (GM) tube type, with an accompanying electronics package which fed square waves (one for each GM pulse) to an electronics package mounted outside the Reactor Building.

The three monitors failed between one day and 218 days following the start of the accident. This is not particularly surprising since such devices were not intended to function during or after an accident. However, these monitors provide examples of insufficient consideration of the effects of failure, a potential lack of testing for all functions, and the effects of field cable on equipment response that could provide misleading information. 
One failure caused an erroneous (10w) indication of the high radiation levels. It was discovered that the area radiation monitor functioned so that high (above scale) radiation levels could result in on-scale readings. The design did have a circuit that was supposed to keep the output above scale for high input radiation levels and it is assumed that the specification correctly required such a feature. However, in the presence of the accident radiation lestimated to be between $2.5 \times 10^{5}$ Rads and $1 \times 10^{6}$ Rads), the circuit did not work. Failure to require proof of performance at high radiation levels resulted in misleading information that could have hampered accident mitigation activities.

A contributor to the incorrect indication of off-scale radiation levels was found to be the length of signal cable between the GM tube electronics package and the electronics outside of the Reactor Building. The cable length was not a factor as the counting rate for the low level radiation; but, at the higher count rates, the cable length distorted the electrical signal, and this gave the appearance of a low level radiation signal. It is not clear whether the installed cable lengths were in excess of specification or whether the specification was deficient.

It should be noted that the three radiation monitors removed for examination experienced failures by three separate mechanisms, unrelated to each other and to the above problem. One failure was due to a cracked GM tube, caused by the overpressure that occurred during the hydrogen burn. The second was due to moisture intrusion caused by incorrect installation. The third unit failed at 218 days after the accident due to GM quench gas depletion and could be considered an expected, age-related failure. In the third case, the unit was not in use during the accident but was energized three months later and worked for five months before failing.

- Loose Parts Monitor Charge Converters 10,11

Charge converters associated with the loose parts monitoring system were found to have failed due to radiation sensitivity of CMOS semiconductors. This failure occurred in the first few days of the 
accident when the system was being monitored very closely to detect loose parts moving through the systems and to assess core damage. This type of failure would mask or distort real loose part signals. The studies at TMI-2 led to the determination that similar failures were occuring during normal operating conditions at another operating nuclear plant. This problem was subsequently corrected through redesign by the manufacturer.

The specification of a required radiation operating level and total radiation dose for this equipment could have led to the use of an alternate design or installation in a location with a lower radiation environment.

- Solenoid Valves

Two $\mathrm{Cl}$ ass $1-\mathrm{E}$ solenoid valves were removed from the Reactor Building air cooling and purge system. Both solenoids were operational except that one limit switch failed to respond to the valve position. One valve shell was rusted from moisture that had entered the solenoid housing, due to a flaw in the configuration of the conduit installation. The limit switch failure was moisture related and the lead wire insulation to both valves had embrittled.

The long-term integrity of these valves could have been improved by assuring protection against moisture intrusion as well as by specifying that all insulation materials be selected for resistance to radiation and thermal aging. Currently there is a wealth of information available on radiation effects on organic materials. *

*M. B. Bruce, M. V. Davis, "Radiation Effects on Organic Materials in Nuclear Plants" EPRI NP-2129, November 1981. 
Applications Engineering

The TMI-2 I\&E Program demonstrated that both safety and non-safety-related instrument and control devices can be affected by adverse environments, and that many of these problems could have been avoided through applications engineering and more appropriate specifications, with only minor design changes being necessary. For this reason the authors suggest the following general guidelines for applications engineering.

Proper and complete applications engineering includes a detailed understanding of the function(s) of the system(s) in which the device is to operate and the function(s) of the device in the system(s) for each state of the plant, including the effects of device failure. This analysis should include considering the effects of failure for plant states where there is no required function in order to assure that the functioning of other equipment is not affected and that operating or technical support personnel are not misled with incorrect information.

Once equipment functions are defined and understood with respect to operating requirements, performance requirements for each plant state can be determined. The expected environments for each of the plant states during which the devices must function (or not fail) should al so be determined. These "environments" are not limited to just temperature, pressure, humidity (or steam), submersion (flooding), radiation, and vibration (both operational and seismic). They should also include the range and characteristics of the power source (including expected transients) and the characteristics of supporting services such as instrument air, cooling water, lubrication (allowable contamination levels, moisture), calibration, and preventive maintenance. These are often overlooked details of applications engineering that affect both equipment reliability and the interpretation of information received, as demonstrated at TMI-2. 
Some basic guidelines to minimize moisture related problems in a nuclear power plant are as follows:

o Install equipment in rooms with no liquid piping.

- Use solid top entry shields on plant located equipment.

o Prohibit top entry cables-conduits into electrical enclosures.

- Specify water tight enclosures.

- Coat electronic circuit boards with conformal coating.

- Seal open conduits to prohibit water entry.

- Instal1 drains and vents.

Applications engineering is essential for the equipment with safety functions, but need not be limited to such equipment. Economic considerations will often also justify this analysis for non-safety equipment needed for operation and management of the plant.

\section{Specifications}

Applications engineering should lead to a complete set of formal specifications which incorporate the above considerations. These specifications would provide a basis for procurement, installation, inspection, and testing to assure that the intended performance is obtained and maintained.

For equipment with safety functions, the specifications should include the requirement that the equipment be environmentally and seismically qualified. $^{12,13}$ Qualification testing will not replace adequate applications engineering, but will confirm the adequacy of the equipment to meet the specifications. If the applications engineering is not done correctly, the testing may only confirm equipment capability to perform to an inadequate specification. 


\section{INSTALLATION AND TESTING}

A number of TMI-2 equipment failures were caused by improper installation practices, which could have occurred during initial installation or during periodic equipment testing when the equipment is replaced. Problems of this type are generally associated with maintenance and can occur even with the best applications engineering and equipment specification.

NRC Staff studies ${ }^{14}$ show that, since 1975, 35\% of the nuclear power plant abnormal occurrences are directly related to maintenance activities. These studies rely heavily on the Licensee Event Reports (LER's) which include such problems (also observed at TMI-2) as connectors installed incorrectly and equipment installed backwards. The LER's do not generally identify the problem of moisture intrusion, as observed at TMI-2, as being a serious problem. The moisture problems identified at TMI-2 were primarily due to faulty seals and inadequate drains and vents. Problems of this type can remain undetected during normal plant conditions, yet may lead to early failure during abnormal conditions or accidents. They may also lead to accelerated aging of some equipment due to long-term exposure to moisture, condensation, and contaminants.

Installation and testing is addressed as a separate section in this report to emphasize its importance and to point out its relationship to the normal plant function of maintenance and surveillance. The U.S. Nuclear Regulatory Commission has documented ${ }^{14}$ the steps being taken by the nuclear industry to enhance maintenance and surveillance.

The TMI-2 I\&E Program findings indicate that the installation of moisture barriers should receive additional attention during design and construction. For existing nuclear plants, it is important that control of moisture be a signficant part of the maintenance program. In addition, electrical circuit testing methods developed by the TMI-2 I\&E Program appear to be of significant value in detecting moisture and related circuit degradation problems before the plant is operationally affected. 
At TMI-2, the installed configuration of some equipment clearly played a major part in their failure under accident conditions. In some cases, these problems resulted in failures during the first twenty-four hours after the accident.

Examples of these problems include pressure and level transmitters, ${ }^{1-3}$ where faulty seals and improper $p 1$ acement of (or failure to instal1) drains and breathers allowed moisture to collect and damage the device internals. The failure of a radiation detector 7 was primarily attributed to the improper orientation of the detector housing, allowing moisture to collect in the connector backshell. The connector itself was improperly assembled. The reactor building dome radiation monitor ${ }^{5}$ had ineffective seals, allowing moisture into the electronic circuitry and degrading instrument performance. Cable or conductor penetrations at electrical devices ${ }^{15,16}$ were particularly susceptible to moisture intrusion.

These findings demonstrate that even simple installation requirements, if incorrectly performed, can degrade the ability of the equipment to function as designed. Particular care should be taken with conduit and junction box seals, drains and vents, and the sealing of connector backshells to protect against moisture intrusion. Design practices should take into account those field activities that are critical so that installation problems are minimized. Installation practices should be controlled to assure they do not degrade the equipment design and application engineering requirements. 
Testing

TMI-2 was a relatively new plant at the time of the accident, providing little information about relationships between testing practices and equipment performance. It was noted that it was necessary to remove the dome monitor during containment leak-rate testing ${ }^{5}$. This removal required opening the sealed container with the risk of damage to the monitor seal and connectors. Many other components are similarly affected during the containment leak-rate tests. Considering the statistical data relating that $35 \%$ of the abnormal plant occurrences are maintenance related, it is an obviously prudent measure to minimize maintenance related activities. In a case such as this, specifying and procuring equipment able to withstand other plant tests without modification or removal should improve equipment reliability. Likewise, designing tests to maximize data for maintenance decisions while minimizing the disturbance of equipment seals will improve equipment reliability.

The Electrical Characteristic and Diagnostic (ECCAD) system developed as part of the TMI-2 I\&E Program demonstrated that it is practical to monitor electrical circuits for information that is indicative of various types of degradation. Using the basic characteristics of resistance and impedance, combined with dissipation factor and circuit resonant frequency, it is possible to identify and describe degradation effects with good accuracy. When supplemented with time domain reflectometry (TDR) information, these techniques provide a valuable tool for analyzing circuit conditions, locating problem areas, and predicting the condition of electrical equipment.

Moisture and related degradation, including shunt resistance and poor or open connections, were detected in many circuits over the course of the program. 
The dominant failure mode of TMI-2 instrument and electrical equipment was due to corrosion. Water and vapor intrusion into the equipment housings caused erratic readings and ultimate failure. Where a reliable seal existed at the cable entry into the I\&E equipment housing, the internals were generally not corroded and the instrument or electrical equipment was operable (if not always within specification). The TMI-2 I\&E Program results cover a period of several years, providing information about the reliability of different installations and the time required for the corrosion process to degrade equipment to the point of failure. The observed degradation and failures over this period and the mechanisms that allow moisture and vapor intrusion have generic operating and maintenance implications.

\section{Findings}

The major cause for I\&E equipment failure was moisture intrusion, as shown for several different instruments listed in Table 1. The major mechanism for moisture intrusion was faulty or inadequate seals on conduits, fittings, housings, and connectors. The TMI-2 post-accident environment was more moist than normal plant conditions, but the number of paths for moisture intrusion, the number of instrument failures, and the extent of corrosion found have generic implications for long-term equipment operability and maintenance practices at operating plants.

These findings are reinforced by the fact that TMI-2 had just begun power operation. Seals had not undergone any significant aging, and there was 1 imited human activity regarding disassembly of connectors or potential damage to conduit, connectors, or housing seals. In operating plants, routine maintenance activities will repeatedly disturb and challenge these seals. 
TABLE 1. TMI-2 INSTRUMENT EXAMINATION RESULTS

\begin{tabular}{|c|c|c|c|c|c|c|}
\hline $\begin{array}{c}\text { I\&E } \\
\text { Equipment }\end{array}$ & Operable & $\begin{array}{c}\text { In } \\
\text { Specification }\end{array}$ & $\begin{array}{l}\text { Failure } \\
\text { Mode }\end{array}$ & $\begin{array}{c}\text { Failure } \\
\text { Cause }\end{array}$ & Mechanism & Remarks \\
\hline CFI-PT -3 & Yes & Yes & & & & $\begin{array}{l}\text { Survived } \\
\text { Several } \\
\text { Years }\end{array}$ \\
\hline CF2-LT-3 & $\begin{array}{l}\text { Failed One } \\
\text { Year After } \\
\text { Accident }\end{array}$ & & $\begin{array}{l}\text { Shorted } \\
\text { Electronics } \\
\text { Corrosion }\end{array}$ & $\begin{array}{l}\text { Water } \\
\text { Intrusion }\end{array}$ & $\begin{array}{l}\text { Inadequate } \\
\text { Seal on } \\
\text { Conduits and } \\
\text { Fittings }\end{array}$ & \\
\hline CFI-PT-1 & Yes & Yes & & & & $\begin{array}{l}\text { Survived } \\
\text { Several } \\
\text { Years }\end{array}$ \\
\hline CF2-LTI & No & $\begin{array}{l}\text { Verified } \\
\text { Failed } 12 / 80\end{array}$ & Corrosion & $\begin{array}{l}\text { Water } \\
\text { Intrusion }\end{array}$ & $\begin{array}{l}\text { Inadequate } \\
\text { Seal Between } \\
\text { Conduit and } \\
\text { Housing }\end{array}$ & \\
\hline CF2-LT2 & No & $\begin{array}{l}\text { Yerified } \\
\text { Failed } 9 / 80\end{array}$ & Corrosion & $\begin{array}{l}\text { Water } \\
\text { Intrusion }\end{array}$ & $\begin{array}{l}\text { Inadequate } \\
\text { Seal Between } \\
\text { Conduit and } \\
\text { Housing }\end{array}$ & \\
\hline CF-1-PT4 & Yes & Yes & & & & $\begin{array}{l}\text { Survived } \\
\text { Several } \\
\text { Years }\end{array}$ \\
\hline CF-2-LT4 & Yes & & & & & $\begin{array}{l}\text { Conduit } \\
\text { and } \\
\text { Breather } \\
\text { Drain } \\
\text { Properly } \\
\text { Installed }\end{array}$ \\
\hline HP-RT-211 & No & & $\begin{array}{l}\text { Shorted } \\
\text { Electrical } \\
\text { Connector }\end{array}$ & $\begin{array}{l}\text { Moisture } \\
\text { Intrusion }\end{array}$ & $\begin{array}{l}\text { Improperly } \\
\text { Made-up } \\
\text { Connector }\end{array}$ & $\begin{array}{l}\text { Human } \\
\text { Error }\end{array}$ \\
\hline$H P-R-214$ & Yes & $\begin{array}{l}\text { No Significant } \\
\text { Measurement } \\
\text { Error }\end{array}$ & $\begin{array}{l}\text { Grounded } \\
\text { Electronics }\end{array}$ & $\begin{array}{l}\text { Moisture } \\
\text { Intrusion }\end{array}$ & $\begin{array}{l}\text { Error in } \\
\text { Installation } \\
\text { of Seal } \\
\text { Assembly }\end{array}$ & $\begin{array}{l}\text { Human } \\
\text { Error }\end{array}$ \\
\hline AH-V 6 & Yes & No & $\begin{array}{l}\text { Falled } \\
\text { Limit } \\
\text { Switch }\end{array}$ & $\begin{array}{l}\text { Moisture } \\
\text { Intrusion }\end{array}$ & $\begin{array}{l}\text { Inadequate } \\
\text { Housing Seal }\end{array}$ & \\
\hline
\end{tabular}


TABLE 1. TMI-2 INSTRUMENT EXAMINATION RESULTS (contd.)

\begin{tabular}{|c|c|c|c|c|c|c|}
\hline $\begin{array}{c}\text { I\&E } \\
\text { Equipment }\end{array}$ & Operabie & $\begin{array}{c}\text { In } \\
\text { Specification }\end{array}$ & $\begin{array}{l}\text { Failure } \\
\text { Mode }\end{array}$ & $\begin{array}{c}\text { Failure } \\
\text { Cause }\end{array}$ & Mechani sm & Remarks \\
\hline PRTS & Yes & $\begin{array}{l}\text { Signals } \\
\text { Shunted } \\
\text { to an Unknown } \\
\text { Extent }\end{array}$ & $\begin{array}{l}\text { Degraded } \\
\text { Cable } \\
\text { Resistance }\end{array}$ & $\begin{array}{l}\text { Moisture } \\
\text { Intrusion }\end{array}$ & $\begin{array}{l}\text { Separated } \\
\text { Conduit } \\
\text { (Damaged) }\end{array}$ & $\begin{array}{l}\text { Due to } \\
\text { Other } \\
\text { Activity } \\
\text { in Area }\end{array}$ \\
\hline
\end{tabular}


The following maintenance precautions should be used to ensure the integrity of I\&E equipment seals:

1. Maintenance and test procedures should contain specific requirements regarding care and installation of conduits, seals, and connectors.

2. After maintenance, where possible, seals should be tested or otherwise verified intact.

3. Connectors should be verified properly as made-up and intact to accomplish their sealing function.

4. I\&E equipment that exhibits anomalous behavior should be investigated for moisture instrusion. Anomolous behavior includes erratic operation, drift, or too-frequent calibrations.

5. Containment close-out checklists should include checks of I\&E equipment for obvious damage to conduits, seals, and connectors. These checks should be done after all work in the general area is completed.

$\underline{\text { Predictive Maintenance }}^{17-19}$

The Electrical Circuit Characterization and Diagnostic (ECCAD) system developed under the TMI-2 I\&E Program, provides an additional means for diagnostics and predictive maintenance for electrical circuits. This system integrates time domain reflectometry with standard impedance measurements in a computer-based measurement system. ECCAD measurements successfully identified a variety of moisture and corrosion problems in TMI-2 electrical circuits from outside the Reactor Building and with minimum disturbance of circuit terminations.

ECCAD data can be compared to electrical standards and criteria for circuit operation. The presence, and of ten the location, of moisture intrusion can be determined, evaluated, and monitored with respect to the effect on circuit function and the need for corrective maintenance of 
conduit, connector, or housing seals. ECCAD signatures al so provide a means to verify remotely that cable terminations have been properly restored following other maintenance and testing activities. These measurements can be performed remotely, efficiently, and with computer-based data management.

Additional information on the ECCAD system is provided in Appendix $A$. 


\section{REFERENCES}

1. R. C. Strahm and M. E. Yancey, TMI-2 Pressure Transmitter Examination Program Year-End Report: Examination and Evaluation of Pressure Transmitters CF-T-PT3 and CF-2-LT3, GEND-INF-029, February 1983.

2. M. E. Yancey and R. C. Strahm, TMI-2 Pressure Transmitter Examination and Evaluation of CF-1-PT1, CF-2-LTT, and CF-2-LT2, GEND-INF-029, Volume II, April 1984.

3. M. E. Yancey, Examination and Evaluation of TMI-2 Transmitters CF-1-PT4 and CF-2-LT4, GEND-INF-029, VoTume III, January 1985.

4. M. E. Yancey, Irradiation Test Report-Foxboro El1GM, Bailey BY3X31A, and Flame Retardant Ethylene Propylene Instrumentation Cable, GEND-INF-058, August 1984.

5. M. B. Murphy, G. M. Mueller, and W. C. Jernigan, Analysis of the TMI-2 Dome Radiation Monitor, GEND-INF-063, February 1985.

6. J. W. Mock, F. T. Soberano, and M. B. Murphy, Quick Look Report on HP-RT-0211 Multivalued Behavior, GEND-INF-008, July T981.

7. M. B. Murphy, G. M. Mueller, and F. V. Thorne, Examination Results of the Three Mile Island Radiation Detector HP-RT-2TI, GEND-014, October 1981.

8. G. M. Mueller, Examination Results of Three Mile Island Radiation Detector HP-R-2T3, GEND-019, November T982.

9. G. M. Mueller, Examination Results of the Three Mile Island Radiation Detector HP-R-2T2, GEND-INF-049, January 1984.

10. M. B. Murphy, R. E. Heintzleman, Examination Results on TMI-2 LPM Charge Converters YM-AMP-7023 and YM-AMP-7025, GEND-020, November 1982.

11. M. B. Murphy, Sequoyah Unit 1 Charge Converter Examination Results, GEND-INF-046, January 1984.

12. IEEE Standard for Qualifying Class 1E Equipment for Nuclear Power Generating Stations, IEEE 323-1974, February 28, 1974.

13. IEEE Recommended Practices for Seismic Qualification of Class 1E Equipment for Nuclear Power Generating Stations, IEEE 344-1975, January 31, 1975.

14. Maintenance and Surveillance Program Plan, U.S. Nuclear Regulatory Commission Policy Issue, SECY-85-T29. 
15. F. T. Soberano, Evaluation Results of TMI-2 Solenoids AH-V6 and AH-V7, GEND-INF-045, January 1984.

16. F. T. Soberano, Testing and Examination of TMI-2 Electrical Components and Discrete Devices, GEND-INF-030, November 1982.

17. H. J. Helbert, et al., TMI-2 Cable/Connections Program FY-84 Status Report, GEND-INF-056, September 1984.

18. L. A. Hecker, H. J. Helbert, TMI-2 Cable/Connection Program: A Look at In Situ Test Data, GEND-INF-042, December 1983.

19. R. D. Meininger, et al., TMI-2 Cable/Connections Program FY-85 Status Report, GEND-INF-068, September 1985. 


\section{APPENDIX A \\ THE ELECTRICAL CIRCUIT CHARACTERIZATION AND DIAGNOSTIC SYSTEM}


Description of System Functions

The Electrical Circuit Characterization and Diagnostic (ECCAD) System is a computer-controlled measurement system designed to characterize electrical circuits in nuclear power plants. EG\&G Idaho, Inc., developed the system at the Idaho National Engineering Laboratory for the U.S. Department of Energy in order to assess the damage to electrical circuits caused by the accident at Three Mile Island Unit 2 (TMI-2). The system has been demonstrated to enhance maintenance activities by diagnosing problems in electrical circuits and can provide a data base for trending electrical circuit conditions.

The ECCAD System characterizes the electrical parameters that might impact the ability of a circuit to perform its electrical function. For example, if the circuit is a motor for a motor-operated valve, the ECCAD System will determine if all connections or contacts are good, if proper voltage can be applied to operate the motor, and if the motor is electrically functional. In order to apply the ECCAD System, the circuit must be interrupted at some point to disconnect electrical leads and connect a lead from the measurement system. The ECCAD System has a built-in capability to check internal calibration prior to each measurement and to confirm that the circuit is returned to its original condition after testing is completed. In application at Shippingport for the NRC Nuclear Plant Aging Research program, 234 circuits were tested over a period of two weeks. In a similar application for Southern California Edison at San Onofre Unit 1, circuits were tested over a period of seven weeks.

Application at TMI-2

The ECCAD System has been used at TMI-2 for two years. More than 750 circuits have been tested. The first circuits were tested in 1 ate 1982 in order to determine if decontamination activities would compound the effects of the accident. Analysts examining approximately 50 circuits 
determined that water sprayed during decontamination work was not making the circuits wetter; rather, the circuits appeared to be drying out. Testing continued in 1983 and 1984 in an effort to screen a large number of circuits at a low cost in order to select the best candidates for removal and examination. At the present, a number of circuits have been tested three times, at one-year intervais.

Description of Electrical Equipment

The ECCAD System is composed of electronic test equipment that is readily available on the commercial market (Figure $A-1$ ). The system is controlled by a Compaq Personal Computer. The computer controls the individual instruments, setting critical factors. It performs a self-test on the systems, and it sequences the instruments. It al so formats the data, ensuring a standard data set of high quality and eliminating much of the operator uncertainty that often plagues long-term (trending) data acquisition.

The ECCAD System makes six basic electrical tests (measurements) and records the data digitally using the test and recording equipment listed in Table A-1. 


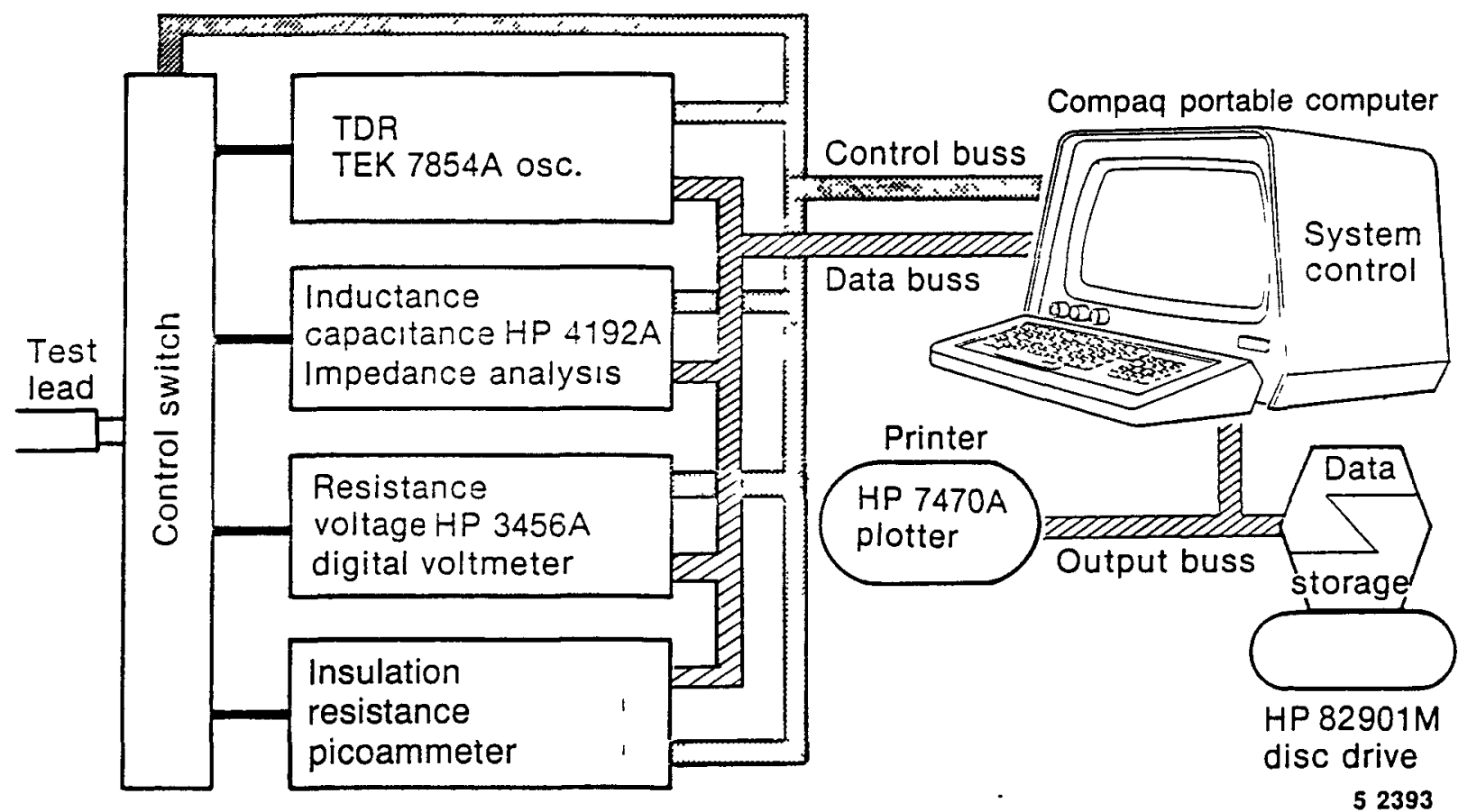

Figure A-1. Electrical Circuit Characterization and Diagnostic (ECCAD) System Block Diagram 
TABLE A-1. ECCAD SYSTEM COMPONENTS

\begin{tabular}{|c|c|c|}
\hline Manufacturer & $\begin{array}{l}\text { Model } \\
\text { Number }\end{array}$ & Function \\
\hline Tektronix & $7854 A$ & $\begin{array}{l}\text { Storage oscilloscope for time } \\
\text { domain reflectometry readings }\end{array}$ \\
\hline Hewlett-Packard & $3456 \mathrm{~A}$ & $\begin{array}{l}\text { Digital multimeter for direct } \\
\text { current loop resistance }\end{array}$ \\
\hline Hewlett-Packard & HP $4192 A$ & $\begin{array}{l}\text { Impedance analyzer for inductance, } \\
\text { capacitance, and resistance } \\
\text { readings }\end{array}$ \\
\hline Keithley & 617 & $\begin{array}{l}\text { High resistance meter for } \\
\text { insulation } \\
\text { resistance }\end{array}$ \\
\hline Compaq & Portable & Personal computer to obtain data \\
\hline Hewlett-Packard & $7470 \mathrm{~A}$ & Plotter to plot data \\
\hline Hewlett-Packard & $82901 M$ & Flexible disc drive to store data \\
\hline
\end{tabular}


The following publications describe this technology or data analyses as described.

1. R. D. Meininger et a1, TMI-2 Cable/Connection Program FY-85 Status Report, GEND-INF-068, September 1985.

This report describes analyses of generic circuits from TMI-2 on the basis of early data. Circuit limitations are discussed which, when compared with the electrical condition of the cable/connections, would imply functional impairment of the circuits.

2. R. D. Meininger, F. T. Soberano, and M. R. Dinsel, "Three Mile Island Techniques to Detect Degradation in Electrical Measurement and Control Circuits", in Proceedings of International Conference on Nuclear Power Plant Aging, Availability Factor, and Reliability Analysis, San Diego, California, July 8-12, 1985.

This paper discusses techniques for evaluating electrical data obtained with the ECCAD System. It discusses aging mechanisms, measurement of circuit degradation, time domain reflectometry, analysis techniques, and gives examples. It points to moisture intrusion into electrical circuits as the most significant operating problem.

3. M. M. Hintze, et al, "Three Mile Island Instrumentation System for Characterization of Electrical Circuits", in Proceedings of International Conference on Nuclear Power Plant Aging, Availability Factor, and Reliability Analysis, San Diego, California, July 8-12, 1985.

This paper describes the Electrical Circuit Characterization and Diagnostic (ECCAD) System developed by EG\&G-ID at Three Mile Island Unit 2. 
4. S. Ahmed, et al, Inspection, Surveillance and Monitoring of Electrical Equipment Inside Containment of Nuclear Power Plants With Applications to Electrical Cables, NUREG/CR-4257, August 1985.

This report describes the general concepts of equipment condition monitoring as applicable to the detection of age-related deterioration of safety-related equipment. It concentrates on cables only, rather than the complete circuit. It emphasizes TMI-2 in situ Time Domain Reflectometry monitoring but does not discuss the A.C. Impedance Measurements found to be valuable at TMI-2. Included is a discussion of the effects of radiation and thermal damage to cable materials.

5. H. J. Helbert, et al, TMI-2 Cable/Connections Program: FY-84 Status Report, GEND-INF-056, October 1984.

This report deals with the first phase of the in situ testing. It identifies anomalies detected during in situ testing and establishes the value of the in situ testing technology which has led to the ECCAD System.

6. L. A. Hecker, et al, TMI-2 Cable Connections Program, GEND-INF-042, December 1983.

This report describes the testing methodology established to test in situ a large number of electrical circuits in order to select samples for removal and further examination.

7. F. T. Soberano, Testing and Examination of TMI-2 Electrical Components and Discrete Devices, GEND-INF-034, November 1984.

This report discusses the TMI-2 accident effects on electrical components as determined by in situ testing. It discusses pre and post decontamination in situ tests and points out that the decontamination spraying did not appear to affect these circuits. These in situ tests are the precursor of the ECCAD 
System, relying heavily on time domain reflectometry, but not utilizing the A.C. Impedance Measurements.

8. R. D. Meininger, et at, "Passive Surveillance: A Technique to Characterize the Condition of Power and Control Circuits in a Nuclear Power P1ant," in Proceedings of IEEE 1985 Symposium on Nuclear Power Systems, San Francisco, California, October 23-25, 1985.

This paper discusses the ECCAD system as applied to TMI-2. The approach, data analysis, and actual examples of data are presented. 